\title{
How Maquiladora Industries Contribute to Mexico-U.S. Labor Migration ${ }^{1}$
}

\author{
Kathryn Kopinak \\ King's University College. Sociology \\ kopinak@uwo.ca
}

Received: 26-07-2010

Accepted: 15-04-2011

\begin{abstract}
While the California corridor of the U.S.-Mexico border is known for its concentration of large maquiladoras, as well as a route for migration into the United States, there has been little research on how maquiladora employment impacts on international labor migration using subjects north of the border. An analysis of data from the Encuesta sobre Migración en la Frontera Norte de México (1993-1997), administered to those returned by the Border Patrol, finds that potential labor migrants with maquiladora work experience differ from the traditional migratory stream of agricultural workers, as well as from those from other occupational groups. They are more likely to be female, single, highly educated, urban, younger, and less likely to be heads of households. Findings from 101 in-depth interviews with persons who have both maquila and other work experience, and who have worked in the U.S., show that male borderlanders are able to best take advantage of opportunities in maquilas to acquire social and human capital facilitating migration. Borderlander women, along with men and women from the interior, with maquila experience also migrate, but have acquired less social capital. This is a result of economic restructuring to bring industry northward. Maquiladoras facilitate workers' migration by helping them to obtain documents. Higher wages are the greatest motivator of labor migration, and are reinforced by age discrimination and a lack of labor law enforcement. In addition, maquila employees also migrate to avoid discrimination, intensity of work, harsh discipline, labor market instability and poor pension benefits.
\end{abstract}

Key words: Maquiladora industries; social capital; human capital; border regions; emigration; skill transfer; exports.

1. The author would like to acknowledge the support of the Center for U.S.-Mexican Studies and the Center for Comparative Immigration Studies at UC, San Diego while researching and writing this article. Funding was provided by the University of California Institute for Mexico and the United States and the Social Science and Humanities Research Council of Canada. The author would like to thank Blanca Torres and Ana G. White for assistance with interviewing, and Donna Maynard for support in data analysis. 
Resumen. Cómo las industrias maquiladoras de exportación contribuyen a la migración desde México hacia Estados Unidos.

Mientras el conocido como "corredor de California», en la frontera de EEUU con México, concentra un gran número de maquiladoras, al mismo tiempo que se conforma como ruta de emigración hacia EEUU, encontramos que es escasa la investigación que analiza el impacto que el empleo en la industria maquiladora tiene en la migración laboral en la frontera norte de México. El análisis de datos de la Encuesta sobre migración en la frontera norte de México (1993-1997) realizada a aquellos que regresaron a México por intervención de la patrulla fronteriza, encuentra que la experiencia laboral en la industria maquiladora actúa potencialmente en la emigración laboral, con lo cual se diferencia de otras corrientes migratorias tradicionales, como los trabajadores agrícolas y otros grupos profesionales. La diferencia viene marcada porque aquellos que emigran, tras tener un trabajo previo en la maquila, son más mujeres, más solteros, con mayor cualificación, más urbanos, más jóvenes y menos cabezas de familia. Por otra parte, los hallazgos de 101 entrevistas realizadas en profundidad con personas que, o bien tienen experiencia laboral en la maquila, o bien tienen otra experiencia laboral, además de haber trabajado en EEUU, muestra que los varones que viven en la frontera aprovechan mejor la oportunidad de trabajar en la maquila con el fin de adquirir el capital social y humano necesario que facilite la migración. De igual modo, las mujeres que viven en la frontera, así como los hombres y las mujeres que vienen del interior de México y han tenido experiencia en la maquila, también emigran, pero con un menor capital social. Este es el resultado de la reestructuración económica que se ha producido tras la relocalización industrial en la frontera norte de México. Las maquiladoras facilitan la migración de los trabajadores ayudándoles a conseguir los documentos necesarios. Por otra parte, los salarios más altos al otro lado de la frontera es la mayor motivación para la migración laboral, reforzado todo ello por la carencia de una adecuada normativa de trabajo y de discriminación por edad. Además del pago, los empleados de la maquila también emigran para evitar la discriminación, la intensidad de su ocupación, la férrea disciplina, la inestabilidad del mercado laboral y las reducidas pensiones.

Palabras clave: Industria maquiladora; capital social; recursos humanos; zonas fronterizas; migración; transferencia de habilidades; exportaciones.

\begin{aligned} & \multicolumn{2}{c}{ Summary } \\ & Introduction Findings \\ & Theoretical Background Conclusion \\ & Methodology Bibliography \end{aligned}

\section{Introduction}

Maquiladoras, also called maquilas, are factories in Mexico that produce for export, paying tax to the Mexican government on the value added. Originating at Mexico's northern border, they have spread throughout the country. However, the greatest number are still in northern regions because most products are exported to the United States. They are sometimes called "twin plants" because multinationals locate operations very close on either side of the border. Production is quite significant for the Mexican economy: in 2006, maquiladora 
production accounted for 55\% of all manufacturing, $45 \%$ of all exports, 34\% of all imports and $21 \%$ of all foreign direct investment in the country (Banco de Mexico 2007).

While the number of maquiladoras have increased considerably since the 1980s, traditional Mexican industries located in the centre of Mexico, producing goods for domestic consumption, have decreased in number and concentration. As subcontractors, maquiladoras link Mexico to the global economy, increase its economic competitiveness, and contribute greatly to human capital. They have also contributed significantly to the commercial power of northern Mexico, increasing their economic importance over almost a half century.

Tijuana, Baja California, which is the western anchor of a largely Asianbased kinescope corridor, is the city with the largest number of maquiladora factories and the second largest number of employees (Kopinak, 2003). In 2006, of the 1,202,132 people employed in maquiladoras, 254,401 of them $(21 \%)$ resided in the state of Baja California or in the municipality of San Luis Rio Colorado, across the state line in Sonora (INEGI). Of these, 69\% worked in Tijuana and Rosarito maquiladoras, $49 \%$ of these workers being women. It is these factories producing for export that have made the Tijuana area the economic giant of the northwest, and the third largest Mexican metropolitan area.

In addition, both Tijuana and the larger state of Baja California have always attracted people from the interior who intend to migrate to the United States. However, very little research has been carried out to study the link between maquiladora employment and labor migration to the United States. Exceptions are Carrillo (1990) and Seligson and Williams (1981), but they only collected data in Mexico and not north of the border, where people who successfully cross end up settling. This paper aims to fill this gap in our knowledge.

\section{Theoretical Background}

The scholarly literature on the relationship between maquiladora employment in Mexico and labor migration to the United States distinguishes three approaches. The oldest approach argued that maquiladora employment curbs or halts international migration. In his 1990 announcement of the NAFTA negotiations, President Salinas said that "Mexico wants to export goods, not people" (cited in Aroca and Malony, 2005: 1). The "goods" referred to are largely produced in Mexico's export processing industries, which has become the main form of manufacturing in Mexico. The quotation reflects his government's policy for both curbing legal migration and halting illegal migration to the United States by providing jobs at home through maquiladora industrialization. The suggestion is that maquiladoras act as a sponge to absorb labor, a type of economic fence impeding labor to cross the border.

On the other hand, Sassen (1996: 222) proposes that "there are many distinct Mexican immigrations" and that "the Border Industrialization Program, ... [has] promoted the formation of a new Mexican immigration, distinct from 
those of the past." Traditionally, migrants from Mexico to the United States have been male agricultural workers, and most migration research has focused on these workers (Cornelius, 1978; Cornelius and Martin, 1993). Sassen regards export processing production, such as that undertaken in maquiladora industries, as uprooting people from their traditional forms of existence and creating new urban reserves of wage laborers. Moreover, foreign investment in maquiladoras has cultural and ideological effects by making international migration an option not only for maquila employees, but also for the wider population in newly industrialized areas.

A middle position has been suggested by economic theorists who argue that international trade (e.g., maquila imports and exports), capital flows (e.g., foreign investment in maquiladoras), and international migration are not necessarily alternative outcomes of the restructuring of the Mexican economy (Razin and Sadka, 2001). Instead, they may constitute complementary, simultaneously occurring, outcomes. While maquiladora industries became a major contributor of jobs in Mexico in the eighties and nineties, when the government abandoned policies of import substitution and instead adopted those promoting export led development, the downsizing and closure of domestic industries contributed to high unemployment in Mexico's central industrial heartland. Further, the promotion of agricultural exports through land reform also created high unemployment among subsistence farmers. In fact, more jobs were lost in traditional sectors of the economy than created via maquiladoras, reinforcing the need for Mexicans to migrate.

The first two approaches are occasionally articulated rhetorically by both those who support export led industrialization and those who are critical. In this paper, the middle position is considered the most feasible. The aim of this article is to discover more about the characteristics of those with maquila experience who migrate to the U.S., how they compare to other migratory streams, what is the motivation for their migration, and how migration was accomplished.

\section{Methodology}

Purist studies with only one method are becoming increasingly rare in the social and behavioural sciences, with more research using both qualitative and quantitative methods (Tashakkori and Teddlie, 1998: 17). In this paper we combine findings from in-depth interviews conducted using Grounded Theory methodology (Glaser, 1998; 1978) with results from a secondary analysis of survey data.

Since 1993, the Encuesta sobre Migración en la Frontera Norte de México $(\mathrm{EMIF})^{2}$ has been carried out annually along Mexico's northern border. From 1995 onwards, interviews have been conducted in eight northern border cities: Tijuana, Mexicali, Nogales, Cd. Juárez, Piedras Negras, Nuevo Laredo, Rey-

2. In English, Survey on Migration at the Northern Border of Mexico. 
nosa and Matamoros. People were interviewed in bus stations, airports, railway stations, international bridges, and Mexican customs inspections points. A random sample of those returned by the U.S. border patrol is also interviewed. ${ }^{3}$ EMIF data bases can be analyzed to better understand whether those having maquiladora experience are likely to migrate to the U.S., but the data have limitations. The surveys were carried out with four migratory currents, but in three of these currents, residents of the border city where the survey was administered are not interviewed. Since the border cities where the interviews are done almost all have large maquiladora labor forces, it can be assumed that if Mexicans with work experience in these factories migrate internationally, many would live in these cities. In none of the four currents are informants who said they lived in the United States asked about their past work experience in Mexico. Thus, we cannot learn from these data about Mexican work experience of migrants who succeeded in staying north of the border.

Only in one of the four migratory currents - those returned by the Border Patrol- were people interviewed if they lived in the city where the interview took place. These data bases do allow for some investigation of the relationship between maquiladora employment and migration to the U.S., since all informants attempted, albeit unsuccessfully, to cross the border, and thus are potential international migrants. The vast majority of the informants in the other three migratory currents said they had never crossed the border to work and did not intend to during their current trip. This finding, however, is probably a methodological artifact since residents of cities where the questionnaires were administered were excluded.

Phases one, two, and three (1993-97) of the questionnaires administered to those returned by the Border Patrol were analyzed because they contain items which specifically ask informants about their work history, and include answers about maquiladora employment. Later phases only ask whether informants worked in industries, and it cannot be assumed that all industries in Mexico are maquiladora industries. Tijuana, for example, has a substantial sector of non-maquiladora industries.

To get a fuller, updated picture of whether those with maquiladora work experience are also labor migrants to the United States, including those workers who had settled north of the border, in-depth interviews were carried out in the San Diego-Tijuana region. A total of 101 interviews were carried out from 2005 to 2008, with five done in Tijuana and the rest in San Diego County. A half dozen of these interviews were of leaders of NGOs, border business groups, US Consulate personnel, and academics who had worked with Mexi-

3. According to Liza Davis, the Public Affairs Officer at the U.S. Consulate General in Tijuana, the United States does not have the capacity to prosecute all those found within the country without proper documents, and legally deport them. The practice is to return many of the undocumented without processing them, arresting people only if they are recognized as having tried to cross many times in a short period. There is no hard-and-fast rule about how long undocumented people have to be in the United States before they are prosecuted and legally deported. (Personal communication, May 24, 2005) 
can migrants. The remaining were of 52 women and 44 men who had worked in Mexico and the US. Out of this group, 30 women and 26 men had worked in maquiladoras in Mexico. Occupations in the U.S. varied extensively, including short order cook, house cleaners, landscapers, teachers, managers, doctors and engineers. Four of those with maquila experience were commuters, while the remaining workers settled in the U.S.. Two commuters intended to move to the U.S. within a year or two after the interview.

Interviews were conducted in San Ysidro (just north of the border), National City, Barrio Logan (home to a large Chicano population), as well as midtown and uptown San Diego. Except for one manager interviewed in Tijuana, most professionals were interviewed in the Rancho Bernardo and Golden Triangle areas, home to numerous large multinational corporations and industrial parks. The interviews on average lasted an hour to an hour and a half.

The two methodologies are complementary. The EMIF surveys were administered using large random samples in many cities along the border, permitting a study of regional effects. Characteristics of potential migrants are compared along several dimensions of work experience. Using Grounded Theory, the in-depth interviews are coded to conceptualize respondents' discourses. With this inductive methodology, researchers begin to build the theory before all data are coded as the findings of the early coding influence subsequent data collection. The evidence indicates three very complex factors. First, the impact maquiladora work has on migration is clearly part of the regional economic restructuring process. Second, labor market factors on either side of the border, such as wages, benefits, job stability or upward mobility, play a crucial role: less people would migrate if there were adequate jobs in Mexico. Third, the ability to obtain documents to enter the United States turns out to be a very important, albeit not a determining, factor in migration.

\section{Findings}

\section{a) Structural and Regional Context:}

Multiple streams of international labor migration exist within different economic and political contexts. The economic restructuring of Mexico since the mid-seventies has transformed regional dynamics, with the North becoming more attractive to both capital and migrants. The restructuring of Mexican industry, changing its focus from import substitution to export processing, brought about important changes to the workplace and has required adopting novel practices for reproducing labor within households. Both of these have led to new streams of international migration.

Cravey (1998: 18) conceptualized this transformation as a transition from the Old Factory Regime, in place from 1930 to 1978, to the New Factory Regime, emerging in 1976 and currently still in force. In the first regime, state owned enterprises provided social programs that facilitated household repro- 
duction for employees. When these were privatized, or greatly downsized, starting in the 1970s, the new factory regime represented by maquiladoras received the state subsidies previously reserved for state-owned companies. Social benefits, where they existed, were more likely to be distributed by maquiladoras - the new normative form of industry in Mexico — to discipline labor. This change in factory regimes was accompanied by other neoliberal reforms, such as withdrawing subsidies from Mexican agriculture, closing CONOSUPO stores that subsidized small farmers so that it was unnecessary for them to migrate, and removing customs barriers to U.S. agricultural products.

An important result of the economic restructuring was the displacement of many Mexicans who now were no longer able to earn a living (Bacon 2007). Many suffered greatly, and were drawn to the northern border where maquiladora industries were creating a new labor force. The effects of the economic crisis and the devaluation of 1994 can be observed in the EMIF data, with those saying they had migrated to the U.S. to work, or look for work, increasing from $83 \%$ in $1993-94$ to $88 \%$ in $1994-95$ and $91 \%$ in $1996-97$ (significant at the .0001 level).

Consider the case of Rodrigo ${ }^{4}$, one of many interviewees who initially had no intention of moving to the northern border or crossing to work in the United States, but then became displaced by the economic restructuring. A civil engineer from Nayarit, he moved with his family to Tijuana in 1985. In Nayarit, he had been part owner of a contracting firm that built schools for the federal government and offices, clinics and hospitals for Recursos y Hydrales, CONASUPO and the Secretaria de Salud. During the economic crisis, which led to the devaluation of 1982, contracts became scarce and competition brutal. He had planned to own his construction firm, but the devaluation ruined him. Maquiladoras at the border boomed in response to the devaluation, since their owners' U.S. dollars, when converted into Mexican pesos, gave them greater purchasing power. Rodrigo worked on both sides of the border as a Superintendent of Construction, building large hotels that sprang up in Tijuana as business expanded, the Centro Commercial de Otay, and maquiladora plants for large companies such as Pioneer and Matsushita. Even though he worked on both sides of the border on a daily basis, he moved to San Diego in 1987 and returned to his family in Tijuana on weekends. While he was not directly employed by the maquiladoras, he worked closely with their managers and engineers to meet their specifications, and was very knowledgeable about their operations. When interviewed at the age of 48, his family had permanently moved to the U.S. a few years earlier because of the high crime rate in Tijuana. He owned several properties in the U.S., and was employed as a unionized construction worker. Meanwhile, his wife, who worked as a secondary school teacher, still commuted each day to Tijuana.

Another interviewee, an administrator in San Diego State University's Bilingual Cross-cultural Teaching Credential program that recruits and trains

4. All interviewees were given pseudonyms. 
bilingual teachers, illustrates how changing regional dynamics expelled professionals from the interior of Mexico to the northern border and then to the US. In the mid-nineties, an increasing number of students in the Sweetwater High School District came from families with a rural Mexican background who were often illiterate, resulting in their children performing poorly in math and science subjects. Since there were insufficient numbers of bilingual teachers in the U.S., the administrators of the program to train bilingual teachers placed an advertisement in a Tijuana newspaper for applicants, offering subsidies for training as well as documents to live and work in the U.S.. Ninety percent of the applicants were engineers who were schooled in the interior of Mexico, and migrated north to work in the booming maquiladoras. However, these engineers felt out-of-place in the maquila work force, believing their professional qualifications were not adequately appreciated. They were attracted by the higher pay and greater opportunity for upward mobility which would be provided by their being awarded the bilingual teaching credential, as well as the opportunity to play a role in demonstrating that Hispanics could excel at math and science when taught in their native language.

One of the remarkable things about this case is that we can see the traditional agricultural stream of migrants being a factor stimulating the new stream of maquiladora employees. Maquiladoras in Mexico play a bridging role in strengthening Hispanic professional classes in the U.S. and in rendering Mexican-American society less truncated. This program only lasted for one generation because of the political controversy surrounding bilingual education and the subsequent difficulty in securing funding (Linton 2007).

Although these engineers who subsequently became teachers arrived in the U.S. legally, the EMIF data collected from those who migrated illegally in the mid-nineties illustrates the two migrant streams discussed in the previous paragraphs. In Table 1, those with agricultural work experience tend to have a socio-demographic profile that differs significantly from those with maquila work experience. Maquiladora workers were comparatively more likely to be women, single, and not heads of households. In addition, maquiladora workers tend to be the youngest, while agricultural workers were typically the oldest. Maquila workers also have a higher education level than agricultural workers. In-depth interviews revealed that many young people had taken advantage of the fact that, at the border, work schedules are arranged so that they can continue schooling full time. These workers were able to avoid a choice between work and school, which Kandel and Massey (2002) found workers in interior locations such as Zacatecas often faced. The last two columns show that maquila workers are much more likely to have been born in (and to live in) urban areas, whereas agricultural workers tend to have been born in (and live in) rural areas. This supports Sassen's idea, cited above, that maquiladoras create an urban reserve of wage laborers who are likely to migrate internationally.

Moreover, maquiladora workers in the EMIF data sets are found to be more concentrated in terms of where they originate from, and specifically 
Table 1. Selected socio-demographic characteristics, by various Labor Force Sectors

\begin{tabular}{lccccccc}
\hline $\begin{array}{c}\text { Labor Force } \\
\text { Sector }\end{array}$ & \multicolumn{2}{c}{$\begin{array}{c}\% \text { Male } \\
\text { Single }\end{array}$} & $\begin{array}{c}\text { \% hhld } \\
\text { head }\end{array}$ & $\begin{array}{c}\text { Mean } \\
\text { Age }\end{array}$ & $\begin{array}{c}\text { \% } \\
\text { Gr. 9+ }\end{array}$ & $\begin{array}{c}\text { \% Born } \\
\text { Urban }\end{array}$ & $\begin{array}{c}\text { \% Live } \\
\text { Urban }\end{array}$ \\
\hline Agriculture & 98 & 56 & 50 & 27 & 26 & 37 & 47 \\
Construction & 100 & 58 & 50 & 26 & 32 & 61 & 78 \\
Business & 87 & 64 & 45 & 26 & 52 & 66 & 83 \\
Domestic Ind. & 93 & 58 & 49 & 26 & 47 & 61 & 78 \\
Maquila Ind. & 81 & 67 & 41 & 24 & 52 & 74 & 90 \\
Tech./Prof. & 97 & 63 & 47 & 25 & 61 & 74 & 87 \\
Other & 79 & 63 & 47 & 26 & 48 & 67 & 83 \\
No Work & 70 & 65 & 32 & 23 & 46 & 61 & 75 \\
Total Sample & 87 & 61 & 44 & 26 & 41 & 58 & 72 \\
\hline
\end{tabular}

EMIF, Returned by Border Patrol 1993-97. Calculations by author with unweighted data Each variable in this table is significant to .0001

more likely to originate from the northern border region. About half of maquiladora workers were born in the six northern border states and around 75\% lived there, higher proportions than we find for the sample as a whole. For agricultural workers, the three highest ranking birth states are Guanajuato, Michoacan, and Oaxaca, but their concentrations there are much lower than the concentration of maquila workers at the northern border. In 1993-94, 25\% of agricultural workers were born and lived in Guanajuato and Michoacan. In 1994-97, 30\% of all agricultural workers were born and lived in these two states plus Oaxaca.

The comments of 43 year old Leticia show that the positive effect of maquilas on migration discussed before may not present itself in non-border regions. Leticia had worked in quality control for several maquiladoras in the Districto Federal in central Mexico.

Interviewer: Do maquila workers finding out about the twin plant on the U.S. side will want to cross the border?

Interviewee: No, because the focus in the centre of the country is very different from that which exists in the north or in rural areas.

Interviewer: Do you think it is more probable that someone who has worked in a maquila will cross the border than someone who has not?

Interviewee: I think that that situation holds in border areas. In border cities it's what the majority of people feel because you are already closer and you know how much you earn in Mexico and how much you earn in the U.S. So in the border it's considered a possibility. But in the centre of the country you don't save to cross the border. In the centre of the country you save to get things. You save to buy a house, you save to buy a car, you save for other kinds of things. It's a very different situation that is experienced in the border areas than is experienced in the centre of the country. 
In contrast to those who were displaced from the interior of the country, those who were settled at the northern border when maquiladoras emerged were less likely to experience dislocation and loss of income. On the contrary, the factories provided those who were at home in the region with opportunities to become highly skilled professionals, embedding themselves at top economic levels. People who have lived at the U.S.-Mexico border for generations are conceptualized as two types of "borderlanders" by Martínez (1994: 60 ). While both types are subject to foreign economic and cultural influence, "national" borderlanders have only minimal contact with the other side whereas "transnational" borderlanders build significant ties with the other nation. The in-depth interviews revealed that maquiladora jobs transformed Mexicans employed at administrative levels in particular from national into transnational borderlanders, and eventually into permanent migrants. Several people were interviewed who can be considered to be part of the transnationalist class that furthers the interests of the global capitalist system (Sklair, 1994). Mexicans raised at the border knew how to manage two different cultures and modes of communication, skills that were highly prized at the upper levels of multinationals. Internal transfers from the maquila in Mexico to operations in the US are usually not permitted, but they nevertheless occur occasionally. Transnational borderlanders above the supervisory grade level often upgraded their skills to qualify themselves for U.S. operations, especially if they wanted to take advantage of goods and services in the U.S. such as quality schools, credit, and good pension plans. Skill upgrading was often acquired with the support of the maquila during employment.

In the new factory regime, the Mexican nation state provides credit, education, training and other services less adequately than the foreign owned private sector. In cities where maquiladoras hire large numbers of people, they have to some extent taken over a number of state functions, acting as a stepping stone for some to secure even better benefits and wages in the United States. As one manager who had worked on both sides of the border explains:

Interviewee: The maquiladora industry was a link for maquiladora employees to migrate to the U.S..

Interviewer: Is this is more true for managers than for operators?

Interviewee: There's some stability for an operator. You can open your own business after being an operator in a maquila. Most maquiladora workers don't finish their education before going into the labor market, and the good thing about working in the maquilas is that you can get training and education through the maquiladora program. In Mexico, nobody is going to give you anything. Here (in the U.S.) there are loans for the military and lots of other groups. Maquiladoras provide options and benefits that are higher than what the federal government would give.

Similarly, Cravey (1998: 92) observed a change in the relationship between Sonora maquilas and the state in the area of health care, with the factories assuming responsibility for such care as more migrants come to fill their jobs. 
The maquila assumption of state functions goes beyond the provision of services and has been shown to have an impact on the segmentation of the labor force. In a study of gender dynamics in Yucatán maquilas, Labrecque (2002) found that, while the state is no longer able to enforce patriarchal structures under neoliberalism, gender inequality is maintained in the maquiladora workplace by illegal practices limiting women's opportunities.

Along with the occasional internal transfer, there were three other ways in which the highly skilled were able to cross the border to work. First, they could use the human capital they acquired in maquiladoras to get U.S. jobs. As a manager in the autoparts sector said:

What I have seen happen is that there is an engineer who is educated in Tijuana working for Panasonic, Sony, one of those big multinationals. If we are talking about manufacturing, there is a concept which is called lean manufacturing that big companies have developed in a very important way and brought to Mexico: the Toyota manufacturing systems in general. So, that person who is educated in that for eight or ten years, begins to search on the internet on Monster for a job in the United States, and finds a small company in some place in California, with three hundred workers that is not global and that has not spent much on those concepts. And, the company sees a person who works in Mexico. They say, come to work with us and we will help you get a visa to work in Escondido or Los Angeles. So, those skills help this person set themselves up well in the United States with a different company.

Second, someone working above supervisory level can make contacts (social capital) while working in a maquiladora that may expedite getting a job higher up in the multinational on the U.S. side. Third, since it is very difficult to continue maquila work starting at middle age because of its intensity, administrators and managers may find a way to work in the U.S. if they do not anticipate having sufficient funds to retire in Mexico. While maquiladoras do not overtly encourage international labor migration, they also do not embed their employees in Mexico. Instead, they are a training ground and staging area for those who migrate. One manager described the maquila effect on migration as a lever or a trampoline, a view also held by Carrillo (1990).

\section{b) The Role of Documents}

The analysis of the EMIF data found that $96 \%$ of migrants had crossed into the U.S. without documents. Those with maquiladora work experience were significantly more likely to have had documents compared to all other occupational groups $(\mathrm{p}=.0001) .{ }^{5} \mathrm{By}$ contrast, the subject of how to obtain documents and use them or the varying kinds of documents available was a strong focus in the interviews of many former maquila employees. A sizable number

5. Because only $1.3 \%$ of the sample had documents, some cross-tabulation cells were very small. Statistical significance of the results should be interpreted with caution. 
of people deliberately seek maquiladora jobs in order to ask their employer for a written statement confirming their employment, which is necessary to obtain documents to enter the U.S. Some maquila employers assist with acquiring documents as part of a "package" of benefits designed to lower employee turnover.

Documents are one of the main explanatory building blocks for a theory to understand maquiladora employment and international labor migration. Documents can be conceptualized as forms of "social control (keeping people in line)" (Glaser, 1978: 77). People with certain kinds of documents must stay within a specific distance of the border, and may or may not be able to work legally. Documents can also be conceptualized as part of Grounded Theory's Six C's: causes, contexts, contingencies, consequences, covariances, and conditions. Documents are a consequence of working in maquiladora factories, and a condition for crossing the border, although not an absolute condition since people cross without them. Having documents may also be a cause of labor migration. Several of those interviewed who never intended to cross to the U.S. to work did so when they lost their maquila jobs. They decided to look for work in the U.S. because they had a document permitting them to enter. This is likely to happen in northern border cities whose main economic base is export processing because there are few other occupational alternatives on the Mexican side, in particular during the maquila downturns of 2000-2004 and 2009 to the present, and also due to greater age discrimination in Mexican labor markets.

From the Mexican side, interviewees crossed without documents, borrowed someone else's documents, applied for a Mexican passport or a US green card. Alternatively, they applied to the U.S. consulate for a tourist visa, a laser visa, or a visa to take care of a sick relative. Inside the U.S., interviewees were able to obtain permanent resident status, citizenship or dual citizenship. Documents were acquired through two main sources: through assistance of a maquiladora employer or one's family. Hernán, a 51 year old interviewee employed in a university cafeteria, had worked in the accounting department of a maquila, registering employees at the Seguro Social. His brother in the U.S. had helped him illegally cross the border the first time he migrated, and Hernán subsequently acquired documents via the Immigration and Reform Control Act (IRCA). He believes migration will proceed faster with family help than with maquila support, saying:

Those who are lucky have a relative or a friend here who can help them try to cross illegally, paying for a coyote, while those who don't have anybody here are going to have to work in Mexico in the maquila and wait longer to be able to cross.

This fact makes labor migration easier for borderlanders, since they are more likely to have family on both sides. Those migrating from the interior are less likely to have this advantage. 
Since all Mexicans crossing legally into the United States must have some form of documentation, not acquiring a legal document is a significant barrier to all forms of migration. This is particularly the case from 1994 onwards, when enforcement at the border was intensified. Nevertheless, four interviewees still reported hiking across the border without documents, with or without the help of a coyote, two of them as recent as six months before the interview. These were men who bought false documents in the U.S.

Not only do maquiladoras provide letters confirming employment in Mexico, as do all employers, but they have also on occasion become part of the U.S. immigration bureaucracy. In the early nineties, when the U.S. converted hundreds of thousands of mica documents ${ }^{6}$ into laser visas, U.S. consulates in northern Mexico worked actively with maquiladora human resource departments to help their workers complete the paperwork. Special "maquila days" were held at the consulate during which maquila workers were transported in company buses to complete the document conversion (Fritsch and Millman, 2001). This is yet another function that maquiladoras have adopted that was previously reserved for the state.

Ordinary workers in maquiladoras were more likely than administrative staff to admit the difficulty of getting hold of documents to enter the U.S. Ruiz (1996) argues that borderlanders use the resources of the border for social reproduction, and maquiladora employment is a resource that has clear benefits in terms of migration. In 2005, only two of the five thousand permanent resident visas offered world wide to unskilled laborers went to Mexicans. Moreover, since 2005, the number of permanent resident visas allocated for Mexicans has been reduced. Although guest worker programs exist, employers tend to avoid them. Preston (2006) argues that when Mexican immigration increased, the U.S. reduced the number of permanent resident visas low skilled Mexicans could acquire. The impact was that henceforth, legal immigrants were admitted more often to join families or for highly specialized job skills. This renders the function of maquiladoras supporting their workers to obtain documents even more important.

The social milieu in the factory provides a space for sharing migration information and offering support for the migration process. Forty-four year old Carlet, a single mother who had held three maquila operator jobs in sevenand-a-half years said:

Well, in the maquila, I heard compañeras saying excitedly, "yes, yes I'm going to get my passport." When we would talk together at lunch, they encouraged me and would tell me: "go ahead, do it." Then, I decided. I went and I did it, but did not even know for a while if they had given it to me. One does not find out, nor get it right away. What happens is that one goes, does the request and fills out the paperwork.... Afterwards, they sent me to a certain office to get an appointment, so I went and that's when they

6. The Border Crossing Card which was issued to Mexican residents allowing them to enter the U.S. to shop and visit was commonly known as the 'mica'. 
finally told me that they were going to grant me the passport. I honestly did not know whether they were going to give it to me or not, nor was I hopeful. Back then [1996] it was not as bad as today; they are very expensive at this point. So, when people get denied nowadays, they feel really bad since it was such a useless expense. [...] At first I only used it to cross to shop, and not to work. But time after time, people told me, you should use it to work. Then I lost my job. Being unemployed was what really pushed me to cross to look for work.

The fact that the acquisition of documents is a collective process of using the maquiladora employer is also evidenced by the fact that workers may loan their documents to co-workers to cross. While the U.S. or Mexican government officials to whom workers apply for documents award them capriciously, maquilas relatively easily give out letters confirming employment. Because of this difference, maquiladoras are an important part of the system used by workers to cross the border, especially during the period when maquilas were assisting the U.S. consulates switch over from micas to laser visas. As a consequence of most large maquilas, such as those in northern Baja California, employing administrators that process requests for letters of support, the new stream of immigrants with maquila experience retains a strong regional basis.

Maquiladoras support workers in their application for documents permitting them to cross, but not to work; this, in turn, influences the type of job migrant workers are able to find in the U.S.. For instance, many former and some current women maquiladora workers clean houses in the U.S., because the senoras who hire them do not ask for work permits while most companies do. These women crossed the border on a tourist or laser visa, neither of which permits employment. People hiring them often ask for a personal reference, or hire former maquiladora workers to clean because they were recommended by someone who already hired them. This particular use of documents to cross legally while working illegally also means that a former maquila worker is often restricted to working in places where he or she has a relative or friend, precisely because they will not ask them for documents.

The following scale of documents was constructed from the in-depth interviews:

(i) Crossing the border without any documents, often on foot, and sometimes assisted by a coyote. If a person does not proceed to any of the following stages, he or she often purchases false documents in the U.S..

(ii) Using one's own U.S. driver's license to legally cross at a port of entry. This happened mostly before more intensive enforcement came into place after $9 / 11$.

(iii) Borrowing someone else's documents, which permit entry but not work or permanent residence: e.g., a Mexican passport, a U.S. tourist visa, a U.S. laser visa, or a visa to care for sick relative. 
(iv) Having one's own documents to cross the border legally, but with no permission to work or legally or reside in the U.S. (same documents as in iii).

(v) Having a green or permanent resident card that permits crossing, working and residing.

(vi) Having U.S. citizenship or dual citizenship that permits crossing, working, residing and even voting.

These are ordered sequentially: a person typically makes several trips to work in the U.S. and uses various documents in the sequence indicated above. These categories are also cumulative. For instance, category (v) (becoming a permanent resident) may depend on obtaining the status entailed by any of categories (i)-(iv), as when people were legalized via the IRCA. Category (vi) ( full citizenship) is in turn dependent on securing category (v). No interviewee went through all of these stages. Most former maquila workers start at stage (iv), but a few did start at the first two. It takes a long time to go through whatever documentation stages the interviewee did, with the result that borderlanders, as well as those who have been settled at the border for many years after migrating from the interior, are more likely to cross to work.

The article argues that those with maquiladora work experience are underrepresented in the EMIF data because they obtained the relevant documents and were less likely to be apprehended. In Table 2, the first column shows a substantial presence of persons with maquila work experience amongst those returned at the border, but this group is not as large as the other occupational groups. In the second column, we observe that almost three quarters of those with maquila experience crossed the border to work or look for work; this is high, but does not reach the level of other occupational groups. Maquiladora workers were more likely than those with other work experience to cross to visit family and friends, to shop, or for entertainment. The migration of those with maquiladora work experience may be less frequently motivated by employment concerns than those with other work experience because they still hold maquila jobs. Several people interviewed in-depth used their documents acquired with maquila assistance to cross and work on their days off, during holidays, or when the maquila cut back their hours because of reduced business. A third explanation for those with maquila work experience to be less motivated to migrate for work reasons is indicated in the third column. The third column presents the striking finding that almost two thirds of those with maquila experience were living in the city where they were interviewed, a much higher proportion compared to those from other work backgrounds (notably agricultural workers at a mere 4\%). Other results showed that those with maquila backgrounds were more likely to reside in the city from which they entered the U.S. Because they are more likely to live in a border city, they can access the U.S. much easier than someone who has to expend time and money traveling just to get to the border. Borderlanders have the luxury of crossing for other reasons besides work. 
Table 2. Total number returned, percentage migrating for work, and percentage living where they were interviewed, by various Labor Force Sectors, 1993-1997

\begin{tabular}{lccc}
\hline \multicolumn{1}{c}{$\begin{array}{c}\text { Labor Force } \\
\text { Sector }\end{array}$} & $\begin{array}{c}\text { Returned by } \\
\text { Border Patrol }\end{array}$ & $\begin{array}{c}\text { Work Motivated } \\
\text { Migration }\end{array}$ & $\begin{array}{c}\text { Lived Where } \\
\text { Interviewed }\end{array}$ \\
\hline Agriculture & 4379 & 96.17 & 3.89 \\
Construction & 3121 & 92.91 & 26.81 \\
Business & 1675 & 83.30 & 27.29 \\
Domestic Industry & 1368 & 90.18 & 17.78 \\
Maquila Industry & 831 & 72.67 & 61.85 \\
Tech./Professional & 844 & 83.37 & 29.57 \\
Other & 2325 & 83.12 & 32.02 \\
No work & 4485 & 78.18 & 26.21 \\
Total Sample & 19028 & 86.67 & 23.07 \\
\hline
\end{tabular}

EMIF, Returned by the Border Patrol 1993-97. Calculations by the author with unweighted data. Each variable in this table is significant to .0001 .

\section{c) The Role of Labor Market Factors}

In the new factory regime comprised by maquiladoras, wages are lower and workers non-unionized or less effectively unionized compared to the old factory regime. In Baja California, the predominant unions are still considered amongst the most subordinated unions of the entire border (Carrillo and Kopinak, 1999). They are often paid by the employer and workers often do not even know they are members.

Labor market factors on either side of the border are a result of regional and political dynamics. The amount of money which can be earned is the most important core variable found in the in-depth interview data, and has many properties or subcores. These include the disorder that is part of the new factory regime, time and stage in the family cycle, which will be elaborated in this section.

While most respondents indicated pay to be an important reason for labor migration, it was much more prominent among former maquila workers than managers or administrators. The pay differences on either side of the border make crossing to work the only rational choice for those who can do it. Women interviewees reported earning as much cleaning two or three houses, taking three or four hours each, as they could working a 48 hour week in a maquila. Managers and engineers earned about three times as much in the U.S. as they did in maquiladoras. Closely linked to the pay variable was "(great) economic need", indicating the difficulty families have making a living on maquiladora wages. Managers and engineers also stressed moving up to the next stage in their careers, or not getting stuck at the bottom rings of the job ladder in their profession in Mexico. 
Prominent among subcodes linked to the pay difference is the lack of enforcement of labor laws in Mexico, which can be thought of fitting Grounded Theory's code family of disorder, or de facto order. Mexican labor law creates an order in the labor force which to a certain degree protects the worker. The lack of labor law enforcement can be seen as disorder, and means that workers who have achieved upward mobility over time can be fired for complaining, and may not receive severance pay when it is legally due. Since the lack of enforcement of labor law is normative, it becomes de facto order. This led Raphael, a 37 year old interviewee who worked in six different maquila jobs and rose to the relatively well-paid position of mechanic, to characterize maquiladora work as "unstable". He was fired when he, with four others, complained that they had not received their annual profit share which they were legally due. They had laid a complaint at the local labor board, but such procedures are lengthy and this quasi-legal government body often favors employers. Long-term employees who lose "good" jobs cannot get a job at another maquila at the former level, but instead have to start at the bottom again. Moreover, if they were fired for complaining or demanding their rights, they may find it difficult to find another job due to black-listing. They certainly cannot give the job they were fired from as a reference. This experience of labor migrants who have worked in maquiladoras for a long time is related to the family life cycle. Raphael first migrated from Morelos to Tijuana with a few friends, with the intention of crossing the border when he was 18 years old. They lived at the bus station and hired one of a multitude of people smugglers. However, he was apprehended and returned two more times by the Border Patrol, then robbed by the Tijuana police. Raphael had no friends or family in the border region, and when his money ran out he took a maquila job. As a young, single man, he could live on maquila wages, sometimes quite well. In addition, at that period in time maquiladoras paid wages in U.S. dollars. However, Raphael was fired when he was married with two small children, his wife earning little as an apprentice hairstylist. The only other jobs he could get were in maquilas at entry level pay, which barely allowed his family to survive. His wife's brother-in-law, who had worked with him in maquilas, had migrated to San Diego to work in a woodwork shop. Raphael worked his maquila job Friday to Monday for twelve hours each day, and went to work with his brotherin-law the rest of the week when there was sufficient work in the woodwork shop. Here we see the co-variance of family and maquiladora employment in the migration process. Raphael crossed the border with a tourist visa he acquired with the support of one of his first maquila employers to use woodworking skills he also acquired through working in the maquilas. His wife and children had no documents to accompany him, which Raphael preferred as he feared harassment by the Border Patrol. Moreover, he did not earn enough to support them in San Diego. Raphael would not have migrated to the US if he was still able to work as a mechanic or could find another comparable job in Mexico.

Compared to workers, managers and engineers are more able to escape the negative effects of the lax enforcement of labor law. If fired, they are 
more likely to be paid severance pay according to law, at a higher rate than what workers receive. Because they are more educated, they can engage the Mexican legal system in their favor, reducing the chances that they will be cheated. This class privilege exists throughout Mexico and is not restricted to the maquiladora industrial regime. Interviewees gave examples of workers in other economic sectors who were not paid compensation when their jobs ended, and their long struggles to receive the money they are due. However, since maquiladoras are one of the major sources of employment in border cities, their employees make up a substantial portion of those having been fired and then go on to migrate to the U.S.

Higher wages in the U.S. were also said to be an "incentive" not to return to maquila work in Mexico. This was the argument of a woman who had worked cleaning houses in the U.S. five days a week for four years, after working for ten years in three different Tijuana maquiladoras. She commuted each day with a tourist visa she acquired with the support of a maquila employer. She said she had no intention to return to maquila work and was in the process of obtaining her green card. She planned to move across to live with her daughter, even though her husband did not intend to migrate with her. Conceptually, this can be understood as part of the Interactive Family of codes (Glaser, 1978), a kind of mutual dependency or interdependence. "This code is an effort to capture the interacting pattern of two or more variables, when the analyst cannot say which comes first. Nor does it matter, probably. For example, rewards lead to motivation to do the rewarded behavior, but also motivation to work leads to seeking rewards. Thus, once the ball is rolling, they feed on each other. They are interactive" (Glaser, 1978: 76).

The comments of Jorge illustrate how wages are related to the focus of the previous two sections, namely regional factors and documents. In 1991 he moved with his wife from a small Veracruz city to Tecate, with the intention of finding a maquila job and then migrating to the U.S.. Jorge was refused a Mexican passport when he applied, but he and his wife secured laser visas from the U.S. consulate with the help of letters of support from maquila employers.

[The maquila] doesn't give you anything to save much money, but it definitely gives you more than a job in the south. On the other hand, by being a job which is at the border, you don't have such problems getting a passport. ... Comparing the border zone to the south, it's much better at the border to make money; although the pay might be the same, at the border you can do more to save. For example, instead of paying for new clothes, at the border you can go to buy clothes in second hand stores.

Such thrift shops are more prevalent in the north because their merchandise is imported from the U.S.. Jorge's decision to move to Tecate and not some other border city demonstrates he carefully considered regional factors: Mexicali was considered too hot, and Tijuana had too many people and too much crime. They did not migrate to the U.S., however, until Jorge was certain his maquila employer was not going to promote him to a job he wanted. Holding an engi- 
neering degree, Jorge was sufficiently qualified, but he said that since those with good maquila jobs do not leave them there is not a lot of opportunity for upward mobility. Thus, low pay, exacerbated by the scarcity of upward mobility, means potential migrants are not embedded in the Mexican side of the border. At the time of the interview, Jorge earned $\$ 3,000$ per month as a busboy, earning in two hours what he would have in his best maquila job by working all week.

\section{d) Gender, Age and Ethnicity as Social Capital}

Social relations that provide access to resources and support for migration are referred to as social capital (Cornelius and Valdez, 2003). Older women have fewer opportunities to work in maquiladoras because maquila employers prefer younger women. A forty-four year old single mother who had migrated to work in a San Jose factory, and again to Chula Vista as a live-in babysitter, spontaneously volunteered the following:

For women, it continues to be really important to work in the U.S. because it's the easiest way to earn money that you have to have to meet basic needs. All women want to earn a good income. But the pay for women's work is low here [in Tijuana]. Older women such as me can't get work here. There are more maquilas all the time, but fewer jobs for people like me. They don't discriminate on the basis of age and gender in the U.S. like they do here, you can keep on working even if you're sixty—not here.

Women's labor migration was also motivated by the stress they had experienced in maquiladora workplaces. Many women preferred the less pressured environment of cleaning houses, compared to the fast pace and high performance environment of the maquiladoras in which harsh discipline was not uncommon. Many said they already knew how to do housework and found it comparatively "easy". Although cleaning houses does not generate the same formal benefits as the maquiladoras, where one might receive a regular bonus for groceries, "if you get along well with the senora, and she likes you, she will help you out more". Women who migrate to do domestic labor earn more money, but do not use the skills learned in maquilas. The exception to this lack of skill transfer is a propensity towards high quality performance, which many said had been impressed on them in maquiladoras.

Two women professionals who had worked as administrators in Asian origin maquilas experienced discrimination from their Japanese supervisors, and preferred to work in the U.S.. One of them was Japanese herself, the daughter of a maquiladora manager, and had grown up in San Diego. She recalled helping her dad in his maquila on weekends when she was a girl:

Their treatment of women is very interesting. Regardless of how much education I had, regardless of how many languages I spoke, regardless of the fact that I graduated from a rather prestigious university, it did not seem to matter to them. I was still considered just as a female office girl. Here [in the U.S.], 
it's completely different. They understand that the chauvinistic mentality is not here so much. And they respect you more. That bothered me immensely, and that was another reason why I left, because I could not deal with that. Because I'm very Americanized. So, that's why I decided, yeah, I think it's time to leave. Like, I told my parents, I didn't go to university for six years just to get them a coffee.

She also characterized them as "just off the boat". The other woman, a Mexican engineer, said that she was held back compared to male engineers with the same credentials hired at the same time. Her Japanese supervisor did not greet her or even speak to her often, and she was required to advise him ahead of time of anything she intended to say in meetings for the first three months of her employment. She was not permitted to communicate with those above her supervisor. Because they were denied the full opportunities available to men in maquilas, women are even less incorporated.

Women are also more likely than men to migrate with documents. A frequent response about this gender difference in the in-depth interviews suggests that women were less likely to migrate without papers because of the danger, especially when accompanied by children. In addition, one interviewee said that maquiladoras were more likely to give women letters of recommendation because they thought women were less likely than men to use the documents to cross the border to work.

Over $82 \%$ of all of those returned by the border patrol in the EMIF data sets had been in the U.S. for only a few hours. Over four-fifths (83\%) were apprehended on the street, on the highway, or while crossing the border. When these data were collected in 1993-1997, the U.S. was in the process of building physical barriers to prevent people from running through customs posts or climbing over fences in large numbers. Potential migrants employed a deliberate strategy to gather at the border and in large numbers climb fences or charge customs posts, and then run as fast as possible in the knowledge that while many would be caught, some would make it through. Today, constructed barriers makes this less likely, so those who intend to cross illegally in the region are required to climb over the mountains in the east, a dangerous enterprise.

The greater difficulty women face when migrating illegally is commonly acknowledged in reporting by journalists. For example, Pilar Rosas crossed the border illegally at San Ysidro at the age of twenty in 1993 (Roberts, 2005). By 2005, she had four U.S. born children and a hard working, reliable husband of ten years. When asked "what's been the greatest challenge of your life here [in San Diego]", she chose this anecdote out of her dozen years of experience: "The biggest problem for me was jumping the fence-I jumped the fence and ran."

\section{Conclusion}

Economic restructuring has created an export platform in northwest Mexico that provides information and opportunities for Mexican borderlanders to acquire documents, as well as human and social capital to assist them to obtain 
better jobs in the U.S.. By contrast, the Mexican state, which has institutionalised the restructuring that created the maquiladoras, does not provide good opportunities for education, training, credit or retirement that are more often available in maquilas or in the U.S.

This article has shown that the concentration of maquiladora industries at Mexico's northern border has contributed to the segmentation of the Mexican immigrant flow northward. Mexican urbanites with maquiladora work experience have joined agricultural workers and other occupational groups in the U.S.. However, the socio-demographic characteristics of maquila workers who migrate differ greatly from those from other occupational groups, and often the opposite of those from agriculture. As with migrants everywhere, the privileged -in this case, predominantly maquila administrators - are able to migrate more easily and to greater advantage sometimes the assistance of their employers. Further, maquiladora workers, especially women, are also more likely than men and other occupational groups to enter the U.S. legally.

Workers more often than administrative personnel ask maquila employers for letters confirming their employment, a requirement to acquire documents to cross the border legally. By contrast, maquila managers and administrators are more likely to rely on maquila employers for training, skill transfers and social contacts in the U.S. While any type of employer might be used for assistance in legal migration, maquiladoras are the main employers in northern Mexico. This is especially true in Baja California, where very large, Asian-based maquilas are global producers, and where employees can learn the latest flexible production processes that can then be used to secure a job in a smaller factory in southern California.

The large pay differences on either side of the border are a central reason for labor migration, and these differences are maintained by both a lack of labor law enforcement and age discrimination in Mexico. This contributes to unstable jobs whose pay does not adequately cover expenses, squeezing income as families grow. Those employed in maquilas are also motivated to migrate for other advantages of working and living in the U.S., including less stressful and intense work environments, less age or gender discrimination, and generally a more secure social environment.

Support for workers to acquire documents is not explicitly intended by either the maquilas or (in some cases) the workers to promote labor migration, but happens primarily because wages do not rise, workers are fired, or during downturns in the maquila industry. Family relations may get one into the U.S. faster, and may be a preferred alternative for getting help to cross the border, but are not usually available for those who have been displaced from the interior of Mexico. This makes borderlanders more likely to migrate, particularly earlier in life.

This study confirms Carrillo's (1990) finding that maquilas are a central part of a two-step process of migration, whereby people move from the interior to the border and take on a maquiladora jobs, and subsequently cross over to the U.S.. This study deepens our understanding of the process by adding to 
this insight that secondary migration often takes place over two generations. Many interviewees had been brought to northern Mexico by parents at a very young age because of job opportunities both in the maquiladoras and in the U.S. Growing up at the border then privileges them in terms of an enhanced ability to migrate to the U.S. The effects of maquiladora employment and living in northern Mexico on labor migration cannot be easily disentangled.

\section{Bibliography}

Aroca, Patricio and Maloney, William (2005). "Migration, Trade, and Foreign Direct Investment in Mexico". Working Paper 3601. Washington D.C.: World Bank Policy Research.

Bacon, David (2007). "The Political Economy of Migration". New Labor Forum, $16(3 / 4), 56-69$.

Banco De Mexico (2007). Informe Anual 2006. México, D.F.: Congreso de la Unión. Carrillo, Jorge and KopinaK, Kathryn (1999). "Condiciones de trabajo y relaciones laborales en la maquila" In: De La Garza, Enrique and Bouzas, José Alfonso (eds.). Cambios en las relaciones laborales. Enfoque sectorial y regional. Vol. 1. México, D.F.: UNAM. 81-149.

Carrillo, Mario (1990). Maquiladoras y migración en México. Puebla: Asesoría y Consultoría Económica.

Corneluus, Wayne (1978). Mexican Migration to the United States: Causes, Consequences and U.S. Responses. Cambridge: Migration and Development Study Group, Center for International Studies, Massachusetts Institute of Technology.

Cornelius, Wayne and Martin, Philip (1993). "The Uncertain Connection: Free Trade and Mexico-U.S. Migration”. La Jolla: Center for U.S.-Mexican Studies.

Cornelius, Wayne and Valdez, Zulema (2003). "Human Capital versus Social Capital: A Comparative Analysis of Immigrant Wages and Labor Market Incorporation in Japan and the United States". Migraciones Internacionales, 2 (1), 5-35.

Cravey, Altha (1998). Women and Work in Mexico's Maquiladoras. Boston: Roman and Littlefield.

Fritsch, Peter and Millman, Joel (2001). "On the Border of Controversy: Maquiladoras Praised, Criticized for Role in U.S. Visa Process" The Wall Street Journal. July 20, P. A1

Glaser, Barney (1998). Doing Grounded Theory: Issues and Discussions. Mill Valley, CA: Sociology Press.

Glaser, Barney (1978). Theoretical Sensitivity: Advances in the Methodology of Grounded Theory. Mill Valley, CA: Sociology Press.

Glaser, Barney and Strauss, Anselm (1967). The Discovery of Grounded Theory: Strategies for Qualitative Research. Chicago: Aldine Publishing Co.

Kanel, William and Massey, Douglas (2002). "The Culture of Mexican Migration: A Theoretical and Empirical Analysis". Social Forces, 80 (3), 981-1004.

KopINAK, Kathryn (2003). "Maquiladora Industrialization of the Baja California Peninsula: The Coexistence of Thick and Thin Globalization with Economic Regionalism". International Journal of Urban and Regional Research, 27 (2), 319-336.

LabrecQue, Marie France (2002). "The Decline of Patriarchy? The Political Economy of Patriarchy" In: Lem, Winnie and Leach, Belinda (eds.). Culture, Economy and Power: Anthropology as Culture, Anthropology as Praxis. Albany: State University of New York Press, 165-176. 
Linton, April (2007). "Dual-Language Education in the Wake of California Proposition 227: Five Cases”. Intercultural Education, 18 (2), 111-128.

Martínez, Oscar (1994). Border People: Life and Society In the U.S.-Mexico Borderlands. Tucson: University of Arizona Press.

Preston, Julia (2006). "Rules Collide With Reality in the Immigration Debate". New York Times. May 29, ??.

Razin, Assaf and SADKa, Efriam (2001). Labor, Capital, and Finance: International Flows. New York: Cambridge University Press.

Roberts, Ozzie (2005). "You are here. Finding your way in San Diego". The San Diego Union-Tribune. April 21, P. E3.

Ruiz, Olivia (1996). "El ir y venir: La relación transfronteriza” In: Ruiz, Ramón and Ruiz, Olivia (eds.). Reflexiones sobre la identidad de los pueblos. Tijuana: COLEF, 56-64.

Sassen, Saskia (1996). "U.S. Immigration Policy Toward Mexico in a Global Economy” In: Gutiérrez, David (ed.). Between Two Worlds: Mexican Immigrants in the United States. Wilmington: Scholarly Resources, 213-228.

Seligson, Mitchell and Williams, Edward (1981). Maquiladoras and Migration: Workers in the Mexico-United States Border Industrialization Program. Austin: The University of Texas Press.

Sklair, Leslie (1994). "Development in Global Perspective” In: SkLaIR, Leslie (ed.). Capitalism and Development. London: Routledge, 165-185.

Tashakkori, Abbas and Teddlie, Charles (1998). Mixed Methodology: Combining Qualitative and Quantitative Approaches. Thousand Oaks, CA: Sage Publications. 